\title{
ECONOMIC ISSUES IN THE INTEGRATED MANAGEMENT OF WATER RESOURCE MODEL (IWRM) AND THE MANAGEMENT UNIT IN A TERRITORY AFFECTED BY SEVERAL BASINS: THE CASE OF THE SPANISH SOUTHEAST
}

\author{
TERESA TORREGROSA \& MARTIN SEVILLA ${ }^{1}$ \\ Applied Economy Department, University of Alicante, Spain
}

\begin{abstract}
The International Water Association bets in its integrated management of water resource model (IWRM) toolbox for a management unit that covers the watershed. However, this point is debatable as there are models of IWRM implementation at the infra-basin level, or even, as in the case we present with this work, when there are several basins that interfere with a particular territory. The problems associated with the confluence of two or more basins in the same territory go through the difficulties in the management of the different resources and their allocation between different uses, especially when the resources are scarce to meet the total demands of water, which occurs in the areas of South-east Spain. Here, global demands are trying to articulate within two deficit basins (the Júcar and the Segura), with external contributions from the Tajo Basin (Tajo-Segura Transfer) and with non-conventional resources from the desalination of seawater. We will try to expose the state of the art at this time, and the alternatives that arise from an economic point of view. Attempts to solve this situation come from far away, even though on many occasions, the economic aspects have not been taken into account, giving rise to investment processes in infrastructures that, due to their costs and the refusal of the users to face them, have generated unstable equilibriums that different governments are incapable to solve.

Keywords: IWRM, Spanish basins, water deficits, share management, scarce resources, water management.
\end{abstract}

\section{INTRODUCTION}

Managers, within the government and in the private sector, have to make tough decisions regarding the allocation of available water resources, since the problems associated with their management have always been interconnected with other aspects such as economic development, politics, economics, or social, environmental and legal factors at different levels. Integrated management of water resource model Integrated water resources management model (hereinafter IWRM) emerged in the 1990s in response to the search for a new paradigm that would encompass the desired holistic dimension of any decision related with the management of an increasingly compromised resource. Although there are various definitions of the concept itself, the most widely accepted one is given by the Global Water Partnership (GWP): WRM is a process that promotes the development and coordinated management of water, land and other related resources, with a view to maximising the resulting social and economic well-being in a fair way, without compromising the sustainability of vital ecosystems. Furthermore, the GWP has developed a dynamic tool known as the "Integrated Water Resources Management Toolbox" (hereinafter IWRMT), which is a compendium of good practices related with the principles of IWRM with a view to providing practical support to professionals from the water sector and key political figures through practical information, guides, case studies, etc., for the correct implementation of IWRM.

${ }^{1}$ Orcid: https://orcid.org/0000-0002-8434-9677 
The integrated approach coordinates the management of water resources with all sectors and stakeholders, at different scales, from local to international. It highlights participation in national processes of law and policy-making, establishing good governability and creating effective normative and institutional agreements that allow more equitable and sustainable decisions to be made. Hence, the bases on which this theory is founded are, chiefly, participation and involvement of all users; a focus on systems that recognise individual components and relations between them in a co-evolutionary way; trans- and multidisciplinary perspective and a balance between the social, economic and environmental values of water. As we can see, the Dublin principles, adopted at the United Nations 1992 International Conference on Water and the Environment, lay the foundations for IWRM [1].

Notwithstanding the above, the key elements that guarantee the applicability of IWRM involve: (1) the existence of appropriate legislation, policies and strategies for the management of water resources; (2) an adequate institutional framework to implement the above and (3) practical management instruments, which allow these institutions to do their job. The emphasis is placed on coordinated decision-making between sectors and scales, recognising that, currently, policies that focus exclusively on supply, which are technology based and very fragmented from a sector perspective, are generating high economic, social and environmental costs that are not sustainable in the mid to long term.

\section{THE IWRM IN THE SOUTH EAST OF SPAIN}

Given the strong support the integrated management approach is receiving internationally and within Europe, several regions of Spain - Río Segura, Cuenca del Duero, Guadiana, Costa del Sol, etc. - have carried out or are currently in the process of carrying out experiments that could be included under the heading of IWRM, even though implementing this model practically can lead to difficulties on account of the institutional and conceptual adjustments that need to be made. Whereas the balance between water supply (resources) and the needs of the population and activities has occupied a substantial proportion of the research conducted in relation to IWRM, the economic and institutional aspects that can make it possible to achieve such a balance have left behind those quantitative issues related with water volumes. Often, we come across surprising situations in which, even with greater access to resources, there is no correspondence with the siltation of demand. Unfortunately, these are not isolated events. This is a major global issue: how to resolve the problem of water management.

It is interesting to highlight that Spain has traditionally taken a joint rather than an integrated approach to management; in other words, the joint management and use of surface and underground waters and, to a lesser extent, non-conventional resources such as treated and desalinated water, ignoring the rest of the premises mentioned previously, which would allow for integrated management. Studies into the joint use of surface and underground waters began in Spain in the 1980s, derived from the enactment of the Water Act in 1985, which considered all water to be public domain. The previous Water Act of 1879 established a distinction between surface and underground waters, which the 1985 modification unified. However, this unification established different transitory rules that, in some cases, run up until the year 2075, and so there are a good number of situations in which this transitoriness is very relevant with regard to the decisions made by the economic agents involved. The Directorate General of Water Works, through the Polytechnic University of Valencia, studied specific cases in the Júcar, Guadalquivir, Sur, Tajo, Duero and Ebro river basins [2]. Spain's Geological and Mining Institute conducted a general national survey and subsequently specific studies in the basins of the rivers Fluviá, Muga, Mijares, Júcar, Guadalentín, Guadalhorce and Guadalfeo [3], but it was not until relatively recently that a true commitment has 
been seen to the application of integrated resource management models. Some examples can be seen in TORREGROSA [4].

The weakest part of applying an IWRM model in the south east of Spain involves the principle of using river basins as the base unit for managing resources. Unlike many aspects of Spain's economic and social activity, which has been gradually transforming following the enactment of the 1978 Spanish Constitution, decentralising competences towards the selfgoverning regions, the management of water has traditionally been linked to drainage or river basins and, therefore, this issue could span several self-governing regions. Thus, eventually, the fundamental competences pertaining to water management were eventually assigned to bodies that reported to Central Government: Confederaciones Hidrográficas or water authorities- now known as river basin districts in accordance with the terminology of the Water Framework Directive (WFD) introduced in the year 2000 - although individual cases were also considered, related fundamentally with the Canary and Balearic islands, known as 'Internal Basins', which are wholly encompassed within a single self-governing region.

The geographical, climatic and historical reality of Spain is very varied, and so, even though legislation is uniform for the whole country, the actual situation on the ground is very different in each of the river basin districts. The traditional distinction between wet Spain and dry Spain is still an important reference when it comes to understanding this issue. The consideration of water as being in the 'public domain' is intrinsically linked to the notion of 'water concession'. The allocation of water to supply cities and industry, and the water used for irrigation, has been carried out by means of concessions made to users (local councils in the case of urban supply and associations of irrigators, chiefly, in the case of irrigation water), so that they can use water for long periods of time, thus guaranteeing access to this resource. Although the oldest concessions cannot have needed a great deal of infrastructure (canals, reservoirs, diversions, etc.) as the population and the irrigated land area gradually expanded and grew, so did the amount of civil engineering work required. In theory, concessions could require the beneficiaries of such works to bear the costs associated with these infrastructures, although subsequently public intervention was required to undertake major investments. Water legislation included part of the costs of these infrastructures under the heading of 'regulation costs' or 'fees for use'; problems of pollution and dumping into rivers opened up the possibility of new fees, elevated to the category of philosophy following the enactment of the WFD in the year 2000, using concepts related to 'cost recovery' and the principle of 'the polluter pays'.

In many areas and districts, there could be seen to be a certain balance between resource availability and demands. But it is clear that, in the south east of Spain, this has not been the case. The major growth of cities and territories along Spain's Mediterranean coast, driven by tourism, has required growing contributions of resources that were not available to users. Furthermore, the climate and soil conditions of these areas, linked with growing demand for fruit and vegetables, fostered the use of water for irrigation that, without a shadow of a doubt, could not be obtained within the territory encompassed by its own drainage basins, or by means of the internal resources available to the districts.

The "Tajo-Segura Inter-Basin Transfer", initiated in the mid-1960s, and which came into operation in the 1980s, radically changed this situation. This action fundamentally changed the very concept of the integrated management of water resources, by contemplating the contribution from an external basin to meet the water needs of the two basins involved: Júcar and Segura. The volumes of water transferred through this project have totalled as much as 600 $\mathrm{Hm}^{3}$ in one year, distributed between urban users and irrigation requirements, chiefly in the 
provinces of Murcia and Alicante, and they have guaranteed much of the economic growth experienced in these regions. The Segura River Basin District was responsible for managing this transfer of water resources, assigning it a dual purpose: on the one hand, as the regulator and adjudicator of the basin's own water resources, and on the other, managing the contributions made by the River Tajo. The management of these volumes of water has brought about conflict between the contributing and receiving basins, which belong to different self-governing regions, even though the ultimate authority in this matter lies with Central Government. The Region of Castilla La Mancha has denounced this practice as being harmful to its own interests (economic and environmental), and so every time water is transferred, administrations come into conflict, and this matter is far from resolved. Some solutions have been proposed, such as changing the point at which water is taken from the river to another location, and even, as set out in the 2004 National Water Plan, by means of a new transfer towards the same areas, but with waters taken from the River Ebro. This solution was ruled out by the change in Government at the time, and because of the lack of resources to implement it. The new government proposed an alternative, the so-called 'Water Plan', based fundamentally on the desalination of seawater and the creation of infrastructures and improvements in water treatment and purification. Together with the above, two important public initiatives complemented the water policy: water savings and the modernisation of irrigation and encouraging the use of regenerated water. The action taken by the public firm SEIASA, in charge of applying the National Irrigation Plan, has led to an important change in the irrigation procedures used in Spain, promoting their modernisation - moving from flood irrigation to drip irrigation systems - and, consequently, major water savings as seen in figure 1 [5].

All of these changes pertaining to the contribution of 'non-conventional' water resources have entailed a substantial alteration to the configuration and responsibility of water managers. Although basin districts are still the main lynchpin in the general regulation of systems, the appearance of different agents to manage these volumes of waters has introduced a new

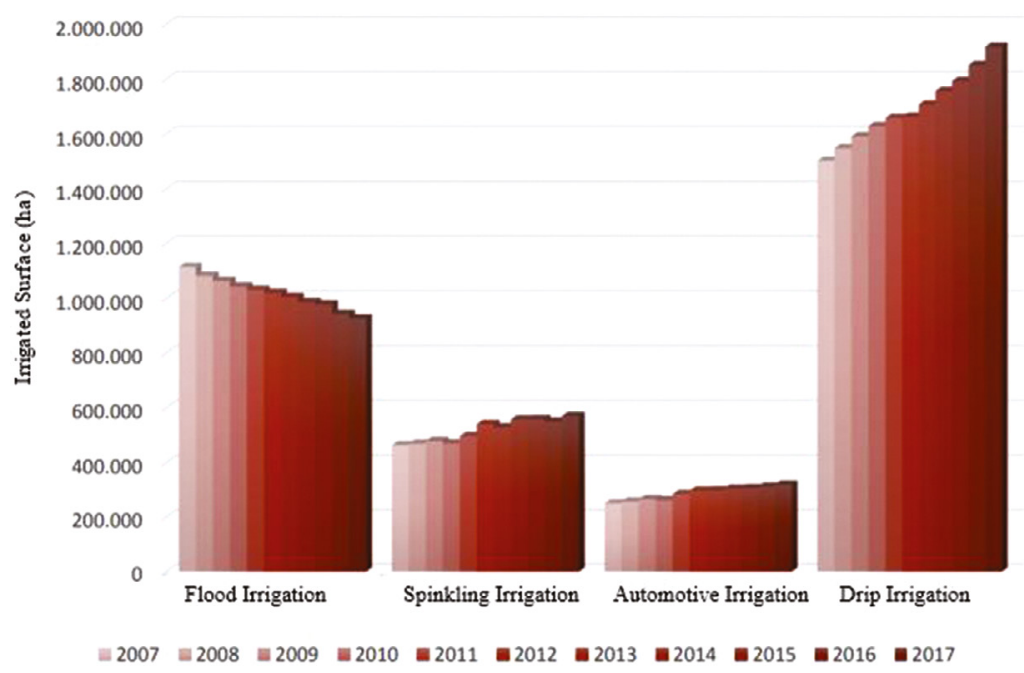

Figure 1: Evolution of the irrigated area according to Irrigation types. Years 2007-2017 (Source: Ministry of Agriculture, Food and Environment, ESYRCE 2017). 
scenario in which the costs of resources and the distribution of their finance impose additional conditioning factors for the final balance of integrated management systems.

\section{THE AGENTS INVOLVED}

The south east of Spain is divided between two river basin districts: Júcar and Segura. However, it occupies the territories of several self-governing regions and provinces: Alicante in the south of the self-governing region of Valencia, the self-governing region of Murcia, and to a lesser extent Almeria in the south west of the self-governing region of Andalusia and Albacete, which belongs to Castilla la Mancha. This adds even greater complexity to the case in point, particularly with regard to the availability and homogeneity of data, since geographical, river basin, territorial, administrative and political borders do not coincide. In this area, there are several instances of the application of IWRM, particularly in reference to the Segura basin district, since this is one of the driest river basins in the whole of Europe, with annual average rainfall of just $365 \mathrm{~mm}$, and in spite of this, it is still a leading region in the export of fruit and vegetables. In the year 2001 many projects were undertaken to recover the River Segura. This river, already under a high water stress levels, worsened its situation since the Spanish entry to the EU. New agricultural products demands from EU members increased water demand pressure and scarcity, in addition to resource pollution that directly affected the river water quality. The GWP [6] states that the policies implemented since that year in the Segura River Basin are a great example of how to integrate social and environmental restoration activities with economic recovery, through a management framework rooted in a solid scientific foundation and with management shared among different public administrations, whereas the river basin management planning process preceded the demands of the European legislation passed subsequently. Furthermore, in the part of the province of Alicante that belongs to the Júcar River Basin District, we conducted a study about IWRM within the area known as the Comarca de la Marina Baja [7] tackling the integration of three aspects - environmental, socioeconomic and political-administrative - within this Comarca, indicating as our main conclusions the existence of a self-sustainable system capable of dealing with substantial urban-tourism and agricultural demands, thanks to the integration of surface and underground water resources, as well as reused treated waters, agreements reached between the users involved and administrative structures that, although they were the weakest link, were working to improve their effectiveness.

Since water understands nothing of administrative or political boundaries, these two districts share many resources, and the legislation specifies that, 'in the case of aquifers that are shared between several river basin districts, each of them is allocated the part of the aquifer corresponding to their respective territory, guaranteeing coordinated management between the affected districts' [8], although the criticisms levelled by users in both districts do not seem to indicate that this stipulation for the joint management of resources is being reflected and even less so implemented. In total, there are 9 shared bodies of water (Sierra Oliva, Jumilla-Villena, Salinas, Quibas, Sierra de Crevillente, Cingla, Sierra de Argallet, Moratilla and Lacera), some of which have been deemed to be overexploited since 1986 - JumillaVillena and Sierra de Crevillente. The recent process undertaken to update and approve the River Basin Water Plans for the period 2015-2021 in both districts has drawn complaints from the users of these waters, especially the Central Association of Users from Vinalopó, Alacantí and the Marina Baja Water Consortium, pointing to the different treatment applied by the water authorities (Confederaciones) responsible for the shared aquifers, both with regard to their classification of the current and future ecological state, as well as who will be 
the beneficiaries of the future Júcar-Vinalopó Inter-Basin Transfer. In the Segura district, they argue that the diversion of water to Vinalopó will allow underwater extractions to be replaced by surface resources from the river Júcar, and this would improve the condition of the bodies of water in the Segura district, since they are shared aquifers. The users of this future interbasin transfer argue that, if the beneficiaries of these waters will also be the users in terms of supply and irrigation water of the aquifers in the Segura basin, they should share the costs and carry out coordinated actions for their joint management, on account of the 'indirect' benefit caused by ceasing drawing water from these overexploited shared aquifers. A clear example of the well-known the tragedy of the commons, defended by the Nobel Prize in Economics Elinor Ostrom [9].

In addition to these traditional agents, such as the Júcar and Segura River Basin Districts, the Mancomunidad de Canales del Taibilla (MCT), the Central Union of Irrigators for the Tajo-Segura Aqueduct (SCRATS) as well as associations of irrigators, the company ACUAMED is now involved, along with SEIASA and the wastewater managers in the regions of Valencia (EPSAR) and Murcia (ESAMUR), as we shall see below. The intervention of all these entities and organisations in the management of water in this area is not neutral. Their actions are not automatically regulated or in line with a common purpose, but instead correspond to criteria set out by their respective upper echelons. Furthermore, the territorial and administrative borders within which they are located do not coincide, bringing about a situation in which decisions can be contradictory, interests can clash and objectives do not always coincide with the resolution of problems in the area.

\section{1 acuaMED (Aguas de las Cuencas Mediterráneas)}

acuaMED is a public corporation that belongs to the State Heritage Group, reporting to Spain's Ministry of Finance, but which acts under the supervision of the Spanish Ministry for Ecological Transition. It offers end-to-end solutions in terms of hydraulic infrastructures, supplying water to associations of irrigators, local councils and companies dedicated to the distribution and supply of drinking water to different types of users. Its activity encompasses the outsourcing, construction, acquisition and operation of all kinds of hydraulic engineering works, within the Segura, Júcar, Ebro, Cuenca Mediterránea Andaluza and Cuencas Internas de Cataluña river basins. The firm carries out its activity through management agreements in place with the Ministry for Ecological Transition (previously the Ministry of Agriculture), which set out the way in which acuaMED must act. These include the construction and/or operation of actions with partial or total recovery of the investment through the participation of private or public users or beneficiaries, and the Construction of Actions without recovery of the investment, to be delivered to the Ministry. acuaMED finances investments using resources from the following sources: its own funds, funds from the European Union, contributions from public institutions, users, beneficiaries or other subjects interested in its actions, by means of financial liabilities operations and/or through the constitution of mixed enterprises. In the area defined, acuaMED owns the desalination plants at Águilas, Valdelentisco, Torrevieja and Mutxamel, as well as the infrastructures of the Júcar-Vinalopó Inter-Basin Water Transfer and the Rabasa-Fenollar canal that connects to the Marina Baja Water Consortium (Benidorm).

In the year 2017, the company registered income of 125 million euros and expenditure of 131 million euros, with the production of desalinated water running below the capacity of its plants. Its dependence on the directives of the Ministry of Finance and the Ministry for 
Ecological Transition made it very difficult to reconcile the objectives set out by them. This company does not present its accounts broken down by each of the areas in which it acts, which makes it difficult to know the scope of the subsidies it applies in each case and whether they are linked to specific policies for each area of action. According to the data made public, contracts for the sale of water to associations of irrigators, especially, are set at lower than cost prices. Logically, a greater production of desalinated water, with higher costs than other conventional sources, generates increased loses in the company's accounts, thus tending to cover these actions in accordance with the so-called 'Drought Decrees' to justify the imbalances.

\subsection{Mancomunidad de Canales del Taibilla (MCT)}

MCT is the body responsible for supplying mains drinking water to municipalities in the area, and it may well have the most clearly defined objectives. MCT, created in 1927, is an independent body, dependent on the Ministry for Ecological Transition. This dependency has not, however, prevented MCT from operating with a high degree of autonomy, and indeed it is currently the main guarantor of the sufficiency of supply to municipalities in the area. MCT does not supply water for irrigation (as acuaMED does), and so its approach presents fewer contradictions than in other cases. To provide services and supplies, it has several sources that have not only varied over time but which also, currently, vary as a function of the different climatological situations, and which are associated with different costs depending on the origin of the water.

Its main sources of supply come from the River Taibilla, the Tajo-Segura Inter-Basin Water Transfer and the desalination that takes place in the plants owned by MCT or purchases made from acuaMED, which has in recent years accounted for average volumes of approximately $200 \mathrm{Hm}^{3} /$ year distributed as follows: 59\% to municipalities in the Province of Murcia and $41 \%$ in the Province of Alicante. This organisation has been able to articulate a system that, during periods of drought, has used the production of desalination plants (with relatively higher costs than other sources) and, in periods of greater availability, has drawn upon conventional sources, reducing output from the desalination plants, thus keeping its repercussion on the prices applied to municipalities within lower parameters according to demand.

The total costs of water drawn from the River Taibilla only incorporate the cost of diverting the water to the consumption centres, approximately $0.05 € / \mathrm{m}^{3}$. The prices applied in 2017 with regard to the Tajo-Segura Inter-Basin Water Transfer were $0.13 € / \mathrm{m}^{3}$, whereas the prices applied for desalinated water were in excess of $0.60 € / \mathrm{m}^{3}$. This disparity has led to the replacement of certain sources by others depending on the climatological situation and the political circumstances being used as a rational instrument of management. With a budget of around 200 million $€$, financial balance has been achieved with earnings from sales of around 127 million $€$, through the sale of water to municipalities, applying rates of $0.69 € /$ $\mathrm{m}^{3}$ (in 2017), charged to all local councils regardless of the distance and difficulty of supply (this is the price that is subsequently taken into consideration by local councils when charging local water rates to users).

The successful operational model of MCT has meant that one of the driest areas in Spain, unlike other areas with greater resources, does not have major problems supplying water to towns and cities and is seen as an important success story in the public management of such a crucial resource. 


\subsection{ESAMUR (Entidad Regional de Saneamiento y Depuración de Aguas Residuales de Murcia)}

ESAMUR is a Regional Public Enterprise created by Law 3/2000, of 12 July, regarding the Sanitation and Treatment of Waste Water and Implementation of the Sanitation Levy, ascribed to the Regional Department of Water, Agriculture and the Environment in Murcia. European and Spanish legislation about the need to treat wastewater was a considerable driving force for these activities in all the regions of Spain. Although authority for this activity was transferred to local councils, practically all Spain's self-governing regions set up regional enterprises to cooperate with them, either on account of the heterogeneity of the cases they had to deal with or because of the insufficiency of their financial resources, and they eventually held de facto authority for sanitation and treatment. Unlike other municipal services (especially those related with municipal urban solid waste), in this case, it wisely linked the financing of this service to supply by means of 'sanitation charges'. In a relatively short period of time, practically all of the urban nuclei in this area had set up their own wastewater treatment plants, which has helped to improve the environment and the situation of surface waters.

Esamur, which operates within the province of Murcia, has made considerable strides, achieving annual water treatment volumes of around $100 \mathrm{Hm}^{3} /$ year. The sanitation charge applied is on average $58 € /$ year for a typical family in $2017-0.30 € / \mathrm{m} 3$ for the domestic consumption charge and $36 €$ a year for the standing service charge - which gives Esamur a revenue of around 50 million euros via the charge, representing almost all of its budget in 2017.

The lack of water resources in the province has meant that Murcia has the highest treated water reusage percentage of any self-governing region in Spain, close to $100 \%$, increasing the resources available with regenerated waters, which have become an additional element in the fight against drought, and in many cases with almost no cost for irrigators, since they are covered by urban consumers under the principle of 'the polluter pays'. However, new EU regulations about the use of treated water for irrigation approved in February of this year posits the need to establish a new investment process to adapt facilities to new requirements, financed by increasing sanitation charges, or by introducing a contribution from the users of reused waters.

\subsection{EPSAR (Public Entity for Wastewater Sanitation in Valencian Region)}

EPSAR was created by Law 2/1992 passed by Valencia's Regional Government on 26 March, as a public entity with its own legal personality, independent from the legal personality of the Regional Government, and with full public and private capacity. In 2017, EPSAR treated 455 $\mathrm{Hm}^{3}$ of water in the Region of Valencia, with a $27 \%$ reusage rate for this water, just below the level achieved in Murcia. According to this entity, of the $123 \mathrm{Hm}^{3}$ reused per year, $51 \%$ correspond to Valencia, $4 \%$ to Castellón and $45 \%$ to Alicante, with agriculture being the primary destination of these waters $(95 \%)$. These figures show that there is still a large margin and much to do to integrate regenerated waters in the joint management process. In spite of the advances made in terms of treatment, EPSAR notes the need to introduce tertiary treatments in the facilities in order to meet the quality requirements for regenerated waters.

\section{CONCLUSIONS}

Postulates about the integrated management of water resources are hampered by many limitations in areas where the imbalances between water resources and demands have led to what is known as 'structural deficits'. In these cases, not only the river basins but also the river 
basin districts (which can include several basins) are insufficient to explain and resolve the possible integrated functioning of all water resources. The explanation is easy to understand since, although resources are in constant tension owing to expectations about their growth through various procedures linked to political initiatives, demands are not limited by pricing systems that could moderate them, especially with regard to water for irrigation.

In the specific case of South East Spain, this panorama has been further impacted by the existence of bodies other than the water authorities, which broadens the range of agents involved in the possible search for balances, but which also have their own resource management strategies owing to their dependence on different administrations (central and regional) or on different ministries. In the case of Spain, the most important entities would be acuaMED, ESAMUR and EPSAR.

acuaMED's dependence on the Ministry of Finance (even though it is overseen by the Ministry for Ecological Transition) means that aspects relative to desalinated water production costs are key for additional contributions of this resource, regardless of the provisions set out in the Water Plans of the basins involved. The cost of desalinated water, regardless of whether it includes the amortisation of investments or not, is more than five times more expensive than the prices applied for the Tajo-Segura Inter-Basin Water Transfer, and so its use as an ordinary resource is prohibitive for irrigated agriculture as it currently stands. Only through specific actions in situations of extreme drought via the 'Drought Decrees' have these waters been accessed at subsidised prices. But these actions are extraordinary. The production of desalinated water as a normal process under current conditions mean that, the more water provided at subsidised prices, the greater the losses incurred by acuaMED. The contradiction of this system is that, if it wishes to minimise losses, desalination plants must be stopped!

These contradictions should be resolved through a new body that would integrate all actions and this would undoubtedly result in a general rise in prices applied to water for all users. The water authorities acting in this area present diverse strategies to resolve the problems they face (in fact, they have not even resolved the theoretically simple problem of shared aquifers), but they do not appear to have a clear awareness or understanding of such difficulties, in view of the Water Plan approved to date or set out for the period 2021-2026, and so over the coming years we will continue to see the same limitations and ad hoc solutions we are seeing today, especially when it comes to irrigation.

Even so, and in spite of the voices that continue to advocate the river basin as the unit of management [10], could a larger or smaller management level to that of the river basin truly not be effective? The model of IWRM presented in Torregrosa [4] for a district in the south east of Spain, covering an area of barely $580 \mathrm{~km}^{2}$, has been in operation since the $1970 \mathrm{~s}$, integrating all demand in the area, chiefly urban and agricultural. Management is in the hands of one supra-municipal body, a consortium, and it uses all the resources it has access to: surface, underground, desalinated and reused water. Although not without difficulties and problems, a sustainable and self-sufficient balance has nonetheless been achieved. It should be noted that this system does have the guarantee of having access to infrastructure that connects this area with other operating systems to bring in external water resources - Rabasa-Fenollar Canal - that, although only used on occasion, naturally provide a backup in case of emergency. Furthermore, the creation of this new supra-basin body could achieve real integration of demands and supplies, neutralising the interests of the agents involved (territorial, political, sector and environmental) in order to achieve sustainable management. Therefore, each case must be analysed in detail in order to draw absolute conclusions about the convenience of using a model of IWRM on one scale or another of application. 


\section{REFERENCE LIST}

[1] UNESCO. Integrated Water Resources Management in Action. WWAP. Jointly prepared by DHI Water Policy and UNEP-DHI Centre for Water and Environment, Dialogue Papers, 2009

[2] López-Geta, J.A. \& Murillo Díaz, J.M., Papel de los acuíferos en la gestión integral de los recursos hídricos. Instituto Tecnológico Geominero de España, Madrid, 2001

[3] Murillo, JM., López-Geta, J.A. \& Hernández Bravo, J.A. Desarrollo sostenible, uso conjunto y gestión integral de recursos hídricos. Estudios y actuaciones realizadas en la provincia de Alicante. Departamento de Ciclo Hídrico de la Diputación de Alicante, e IGME, 2010

[4] Torregrosa, T., El modelo socioeconómico de gestión de los recursos hídricos en la Comarca de la Marina Baja (Alicante), un enfoque de Gestión Integrada de Recursos Hídricos. [The socioeconomic model for wáter management in Marina Baja District (Alicante), An approach for an Integrated Water Resources Management Model" Doctoral Thesis, Applied Economic Department, University of Alicante, 2008]

[5] ESYRCE (2017) Survey on surfaces and crop yields. Report on Irrigation in Spain. Ministry of Agriculture, Food and Environment, Madrid. In Spanish: ESYRCE (2017) Encuesta sobre superficies y rendimientos de cultivos. Informe sobre Regadíos en España. Ministerio de Agricultura, Alimentación y Medio Ambiente, Madrid.

[6] GWP, Spain: Segura River returned to its health. Case Study No.478, Developed for the Global Water Partnership Toolbox, 2016

[7] Torregrosa, T., La gestión del agua en la Marina Baja (Alicante) Temas de las Cortes Valencianas, 19. Ed, Cortes Valencianas, Valencia, 2009

[8] Artículo 1.3, Real Decreto 125/2007 de 2 de febrero, Royal Decree 125/2007, February $2^{\text {nd }}$ by which the territorial scope of the Hydrographic Demarcations is settled.

[9] Ostrom, E., El gobierno de los bienes comunes: la evolución de las instituciones de acción colectiva. Fondo de Cultura Económica, México, 2000. Original Ostrom, E., Governing the commons: The evolution of institutions for collective action. Cambridge University Press, 1990

[10] Fanlo Loras, A., Las competencias del Estado y el principio de unidad de gestión de cuenca a través de las Confederaciones Hidrográficas, Revista de Administración Pública, no 183, Madrid. Sep-dic, pp. 309-334, 2010 